\title{
$\cdot \dot{\gamma}$ IJCRR \\ Section: Healthcare \\ Evaluation of the Hepatoprotective Potential of Adiantum capillus Against Carbon Tetrachloride- Induced Hepatopathy in Rodents
} ISI Impact Factor (2019-20): 1.628 IC Value (2019): 90.81 $\operatorname{SJIF}(2020)=7.893$

(c) (i) (3)

Copyright@IJCRR

\section{Raziuddin Khan ${ }^{1 *}$, Madan Kaushik², Zeashan Hussain ${ }^{1}$}

'Mahatma Gandhi Institute of Pharmacy, Junabgunj, Kanpur road, Lucknow-227101, India; 'Adarsh Vijendra lnstitute of Pharmaceutical Science, Shobhit University, Gangoh, Saharanpur-237341, India.

\section{ABSTRACT}

Introduction: Adiantum capillus (AC) Linn (Family: Adiantaceae) commonly known as "Hansraj" It is used in common cold, cough, pyrexia inflammation, acts as purgative. It improves digestion and renal function.

Objective: To investigate the hepato-defensive potential of $A$. capillus in contradiction of carbon tetrachloride tempted hepatic damage in rats.

Methods: The rodents were dosed with $50 \%$ ethanolic extract of $A$. capillus (dose 100, 200, and 300mg/kg. p.o.) against CCl4 induced hepatic damage.

Results: CCI4 elevated the level of hepatic markers like SOPT, SGPT, bilirubin and ALP as well as altered the antioxidant enzymes. The level of hepatic biomarkers, as well as antioxidant enzyme, were recovered after the administration of at 100,200 and $300 \mathrm{mg} / \mathrm{kg}$, p.o. among all the doses $300 \mathrm{mg} / \mathrm{kg}$ showed the better hepatoprotective potential which was further confirmed by the histopathological.

Conclusion: The $50 \%$ ethanolic extract of $A$. capillus (ACE) recover the biochemical as well as antioxidant parameters, which were affected by $\mathrm{CCl} 4$. The histopathological analysis supports the outcomes of antioxidants parameters.

Key Words: Adiantum capillus, Hepatoprotective activity, SGOT, Antioxidant, CCI4, Histopathology

\section{INTRODUCTION}

The liver is the largest gland in the body and weight about $1.4 \mathrm{gm}$. The liver is detoxified and metabolize different drugs and xenobiotics by cytochrome P450 (CYP) enzymes and add polar functional groups onto a drug molecule. cytochrome belongs to the isozymes family which are responsible for the reduction and hydrolysis of organic molecules. ${ }^{1}$ Liver diseases, which are still a world health problem, may be divided into acute or chronic hepatitis (inflammatory liver diseases) and cirrhosis (degenerative disorder due to fibrosis in the liver). Treatments of liver diseases are disputed because conventional or synthetic drugs for the treatment of these diseases are no up to mark and causes side effects. ${ }^{2}$ Liver diseases are shown the highest mortality among all the digestive diseases. Adiantum capillus-veneris Linn (Family: Adiantaceae) commonly known as "Hansraj, avenca and maidenhair" ${ }^{\prime, 4}$ cultivated throughout India, Srilanka and many tropical countries. Adiantum capillus (AC) is used in cold and cough bronchitis, inflammation, fever, liver and skin diseases. It is also used as a stimulant, emollient and purgative to improve appetite, digestion, stimulate renal function febrifuge, galactagogue and alopecia. ${ }^{5}$ The extracts of the Adiantum capillus (ACE) leaves have anti-inflammatory, analgesic and anti-microbial activities. ${ }^{6}$ Adiantum capillus (AC) contains flavonoids, alkaloids, tannins, saponins, glycosides, steroids and terpenoids. Adiantum leaves extract contains a high level of flavonoids that are a good source of antioxidants. ${ }^{3}$ The major chemical constituents of Adiantum capillus are 5-7A-Isoprpenyl-4,5-dimethyloctahydro-1h-inden-4yl)-3-methyl-2-Penta,n-hexadecanoicacidandgammasitosterolcis-vaccenicacid,5-7A-Isopropenyl-4,5-Dimethyloctahydro-inden-4-yl)-3-methyl-pent-2-EL9. Isolated new terpenoids that were 22, 29-epoxy-30- norhopan-13-ol from the Adiantum capillus leaves with strong antibacterial activity. 3- coumaroyl quinic acid, kaempferol-3-glucosides as a major phenolic compound. ${ }^{7}$

\section{Corresponding Author:}

Raziuddin Khan, Assistant Professor, Mahatma Gandhi Institute of Pharmacy, Junabganj, Kanpur Road, Lucknow-227101, Uttar Pradesh, India; Contact: +91 8090183694; E-mail: pharmarazi@gmail.com

ISSN: 2231-2196 (Print)

Received: 11.08 .2020
ISSN: 0975-5241 (Online)

Revised: 12.10 .2020
Accepted: 22.12 .2020
Published: 04.06 .2021 
There is no work reported work on hepatoprotective activity of Adiantum capillus. Hence, the present study was carried out to evaluate the hepatoprotective activity of Adiantum capillus against $\mathrm{CCl}_{4}$ induced liver toxicity in rats.

\section{MATERIALS AND METHODS}

\section{Collection and identification of Plant material}

Plants were freshly collected and authenticated at National Botanical Research Institute, Lucknow and a voucher specimen (NBRI-SOP-201) for the collected sample has been submitted for future reference.

\section{Preparation of extract}

The whole plant of Adiantum capillus (AC) was freshly collected and subjected to shade-dried the dried whole plants were milled to a coarse powder. Successive extracts of Adiantum capillus veneris Linn whole plant powder was prepared using soxhlet apparatus petroleum ether $\left(50-80^{\circ} \mathrm{C}\right)$, chloroform and $50 \%$ ethanol. The extracts were filtered, pooled and concentrated through a rotary evaporator.

\section{Phytochemical test}

A phytochemical screening test of $50 \%$ ethanolic extract of Adiantum capillus was performed for alkaloids, carbohydrates, flavonoids, glycosides, triterpenoids, resins, saponins, steroids and tannins as per reported method. ${ }^{8,9}$

\section{Experimental animals}

Wistar rats weighing $140 \pm 20$ gm were used for the study. They were kept in well-ventilated cages at room temperature $\left(24 \pm 2^{\circ} \mathrm{C}\right)$ and relative humidity respectively. Animals were given with pellet diet (Bharat Ansh Scientific Industries, Lucknow) and the food was stopped 18-24 h before the experiment, water was allowed ad libitum. The Institutional Animal Ethics Committee of the Mahatma Gandhi Institute of Pharmacy, Lucknow (1957/PO/Re/S/17CPCSEA), approved the protocol.

\section{Acute toxicity studies}

The oral toxicity study was performed as per OECD-423 guideline. The pilot study was done by using three rats per treatment. 50\% ethanolic extract of Adiantum capillus (ACE) extract was given at up to $2 \mathrm{~g} / \mathrm{kg} .{ }^{10}$

\section{Hepatoprotective Activity}

Wistar rats $(140 \pm 20 \mathrm{~g})$ were categorized into six groups, each group having six rats. Group, I served as control, given a single dose of carboxymethyl cellulose $(1 \mathrm{ml}$ of $1 \%$, w/v/ p.o.). Group II given Carbon tetrachloride $(1 \mathrm{ml} / \mathrm{kg}$ body weight, i.p., 1:1 v/v mixture of $\mathrm{CCl}_{4}$ and olive oil) alone, while group III given orally $100 \mathrm{mg} / \mathrm{kg}$ silymarin and group
IV, V and VI given 100, 200 and $300 \mathrm{mg} / \mathrm{kg}$ body weight of $50 \%$ ethanolic extract of $A$. capillus (ACE) in $(1 \%, \mathrm{w} / \mathrm{v}$, $\mathrm{CMC}$ ) respectively along with Carbon tetrachloride as in group II. The $50 \%$ ethanolic extract of Adiantum capillus (ACE) was given daily while Carbon tetrachloride was given every $72 \mathrm{~h}$ for 14 days. Animals were sacrificed $48 \mathrm{~h}$ after the last dose of the drug. Blood samples and tissue (liver) were collected ${ }^{11}$. The serum was separated for biochemical estimation.

\section{Histopathological studies}

For histopathologic analysis, samples of the liver are obtained from all groups and stare in $10 \%$ phosphate-buffered formalin dehydrated in graded (50\%-100\%) alcohol and embedded in paraffin, sectioned at $(5 \mu \mathrm{M})$, and stained with routine hematoxylin and eosin (H\&E) stain for photomicroscopic assessment

\section{Antioxidant activity}

The liver was clean with ice-cold saline to remove as blood residue. The liver was homogenized in ice-cold $0.9 \%$ sodium chloride solution with a Potter- Elvenhjem glass homogenizer. The homogenate was separated at $840 \mathrm{rpm}$ for $15 \mathrm{~min}$ and the supernatant was again separated at $1200 \mathrm{rpm}$ for $15 \mathrm{~min}$ and the got fraction was used for Lipid peroxidation (LPO), Catalase (CAT), Superoxide Dismutase (SOD), and Reduced Glutathione (GSH) activity estimation.

\section{Lipid Peroxidation (LPO) assay}

Homogenate was dissolved with $0.2 \mathrm{ml}$ of an $8.1 \%(\mathrm{w} / \mathrm{v})$ sodium dodecyl sulfate solution, $1.50 \mathrm{ml}$ of a $20 \%$ acetic acid solution and $1.50 \mathrm{ml}$ of a $0.8 \%(\mathrm{w} / \mathrm{v})$ solution of TBA and make up the volume, $4.0 \mathrm{ml}$ with distilled water. Every vial was tightly packed and heated in a boiling water bath for $60 \mathrm{~min}$, cooled with water. An equal volume of incubated samples and $10 \%$ trichloroacetic acid were placed into a centrifuge tube, mixed well and centrifuged at $1000 \mathrm{rpm}$ for $10 \mathrm{~min}$. The absorbance of the supernatant fraction was measured at $532 \mathrm{~nm}$. TBA was replaced with distilled water served as control. ${ }^{12}$

\section{Reduced Glutathione (GSH) assay}

The concentration of GSH found the basis on the development of a yellow colour when 5,5'-dithiobis (2-nitrobenzoic acid) was added to compounds having sulfhydryl groups. The mixture having $4 \%$ sulfosalicylic acid and tissue samples homogenized in 4 volume of ice-cold $0.1 \mathrm{ml}$ phosphate buffer $(\mathrm{pH} \mathrm{7.4)}$. The procedures used for determining the Glutathione and determine the nonprotein sulfhydryl concentration inclusive of Glutathione. Enzyme activity was expressed as milligram per hundred gram. ${ }^{13}$ 


\section{Assay of Superoxide Dismutase (SOD)}

Superoxide dismutase scavenges the superoxide radical $\left(\mathrm{O}_{2}\right)$ and thus provides a defence against free radical damage $.0 .5 \mathrm{ml}$ of liver homogenate was diluted with water, $0.25 \mathrm{ml}$ ethanol and $0.15 \mathrm{ml}$ of chloroform. The composition was centrifuged at $2000 \mathrm{rpm}$ and mixed with $0.5 \mathrm{ml}$ of the supernatant. Superoxide dismutase performance was measure as $\mathrm{U} / 1$ change in optical density per minute at $50 \%$ reduced to adrenochrome transition. ${ }^{14}$

\section{Assay of Catalase}

In animals, catalase is present in all organs, especially being concentrated in the liver and erythrocytes. During $\beta$-oxidation of fatty acids by flavoprotein dehydrogenase, hydrogen peroxide was generated, which was accepted upon by catalase present in peroxisomes. To $0.1 \mathrm{ml}$ of liver homogenate, $1.0 \mathrm{ml}$ of each phosphate buffer and hydrogen peroxide were added and mixed. The reaction was initiated by the addition of a $2.0 \mathrm{ml}$ dichromate acetic acid reagent and heated on the water bath. The green colour was developed, absorbance was taken at $570 \mathrm{~nm}^{15}$.

\section{Statistical Analysis}

The results were shown as Mean \pm SEM. Statistical data was measured by Graph pad prism software, a one-way ANOVA statistical program. The obtained results were considered significant at $\mathrm{P}<0.05$.

\section{RESULT}

\section{Phytochemical investigation}

The phytochemical investigation showed the presence of various phytoconstituents like carbohydrates, alkaloids, phenols, flavonoids, saponins, tannins and triterpenoids in extracts.

\section{Acute toxicity studies:}

Ethanolic extract of $A$. capillusi (ACE) did not show any behavioural change and mortality up to the $2000 \mathrm{mg} / \mathrm{kg}$ dose level. Therefore, one-tenth $(200 \mathrm{mg} / \mathrm{kg})$ of the $2000 \mathrm{mg} / \mathrm{kg}$, just half of $1 / 10^{\text {th }}(100 \mathrm{mg} / \mathrm{kg})$ and just double of $1 / 10^{\text {th }}$ half (300mg/kg) were selected as the dose of $A$. capillusi extracts.

\section{Hepatoprotective activity}

Effect of ACE on serum hepatic biomarkers parameters The consequence of various doses of $50 \%$ ethanolic extracts of $A$. capillus (ACE) was studied on serum marker enzymes like SGOT, SGPT, total bilirubin (TBB), direct bilirubin (DBB) and ALP. The hepatic bruise due to toxic dose of $\mathrm{CCl}_{4}$ significantly $(P>.0 .001)$ rise the level of enzyme SGOT by $264.98 \%$, SGPT by $380.96 \%$, TBB by $200 \%$, DBB by
$664.70 \%$ and ALP by $132.66 \%$ compared to the control group.

The dose of extract, ACE 100 (Group-IV), ACE 200 (Group $\mathrm{V})$ declined the elevated level of SGOT $41.66 \%(\mathrm{P}<0.05)$, $71.14 \%$ ( $\mathrm{P}<0.001)$, SGPT 35.96\% ( $<<0.05), 55.97 \%(\mathrm{P}$ $<0.01)$, TBB 53,33\% $(\mathrm{P}<0.05), 96.66 \%(\mathrm{P}<0.01) \mathrm{DBB}$ $25.66 \%(\mathrm{P}<0.05), 55.30 \%(\mathrm{P}<0.01)$ and ALP 49.25\% $(\mathrm{P}<$ $0.05), 74.24 \%(\mathrm{P}<0.01)$ as compared to group II. The dose of extract, ACE 300 (Group VI), declined the maximum level of SGOT 97.65\% (P<0.001), SGPT 97.72\% (P<0.001), TBB 110.4\% $(\mathrm{P}<0.001)$ DBB 77.61\% $(\mathrm{P}<0.001)$ and ALP $97.55 \%$ ( $\mathrm{P}<0.001)$ compared to group II. Similarly, silymarin decrease the level of SGOT 96.64\% (P<0.001), SGPT 95.23\% ( $\mathrm{P}<0.001)$, TBB 115.40\% $(\mathrm{P}<0.001)$ DBB 80.08\% $(\mathrm{P}<0.001)$ and ALP 97.32\% $(\mathrm{P}<0.001)$ compared to group II. The results are tabulated in Table 1.

\section{Effect of ACE on GSH, LPO, CAT and SOD level}

In our study, the $\mathrm{CCl}_{4}$ treated group showed a significantly elevated MDA level of $247.5(\mathrm{P}<0.001)$ compared to group I. However, rats treated with different doses of ACE 100 (Group-IV), ACE 200 (Group V) and ACE 300 (Group VI) significantly declined the elevated level of MDA as $47.47 \%$ $(\mathrm{P}<0.05), 73.73 \%(\mathrm{P}<0.05)$ and $93.99 \%(\mathrm{P}<0.01)$ as compared to group II.

ACE treated groups had significantly elevated the level of $\mathrm{GSH}, \mathrm{CAT}$ and SOD content whereas $\mathrm{CCl}_{4}$ intoxicated group had shown significant decrease in these parameters compared to control group. The dose of extract, ACE 100 (Group-IV), ACE 200 (Group V) and ACE 300 (Group-VI) elevated the declined level of GSH 28.57\% ( $<<0.06), 50.87 \%(\mathrm{P}<0.05)$ 70.01 ( $\mathrm{P}<0.01)$, CAT 40.21\% ( $<<0.05), 56.91(\mathrm{P}<0.05)$, $86.89 \%(\mathrm{P}<0.01)$.and SOD 36.25\% $(\mathrm{P}<0.05), 65.56 \%$ $(\mathrm{P}<0.05), 90.42 \%(\mathrm{P}<0.01)$ as compared to group II. $\mathrm{Si}-$ lymarin (Group III) elevated the level of GSH 82.45\%, (P< 0.001), CAT $89.99 \%$, ( P < 0.01), SOD 96.18\%.( $\mathrm{P}<0.001)$ as well as decrease the level of MDA 94.94\% $(\mathrm{P}<0.01)$ as compared to group II. The results are tabulated in Table 2. In different doses the level of ACE, $300 \mathrm{mg} / \mathrm{kg}$ shown the maximum protection.

\section{Histopathological Studies}

The histological observations help the results obtained from serum enzyme assays Histopathology of the liver section is well described in Figure 1.

\section{DISCUSSION}

In the present investigation, $\mathrm{ACE}$ hepatoprotective activity using $\mathrm{CCl}_{4}$ was evaluated in the rat. $\mathrm{CCl}_{4}$ is a toxic compound, which metabolized by the action of cytochrome P450 that leads to the formation of unstable and complex 
metabolites of $\mathrm{CCl}_{4}$ which may cause hepatotoxicity. $\mathrm{CCl}_{4}$ is stimulated in the presence of cytochrome $\mathrm{P}_{450}(\mathrm{CYP} 2 \mathrm{E} 1)$, and (CYP2B, CYP3A) both are converted $\mathrm{CCl}_{4}$ to its metabolites such as tri-chloro-methyl $\left(\mathrm{CCl}^{*}\right)$ free radicals convert into trichloromethyl peroxy radical $\left(\mathrm{CCl}^{3} \mathrm{OO}^{*}\right)$ in the presences of oxygen. $\mathrm{CCl}_{3}$ free radical covalently binds to the biomacromolecules and $\mathrm{CCl}_{3} \mathrm{O} 2$ involves lipid peroxidation to dissolve the polyunsaturated fatty acid and change it into a small fragment called MDA or 4-hydroxynonenal. The free radicals alter the integrity of the cell membrane due to the oxidation of polyunsaturated fatty acid in cellular membranes. ${ }^{16}$

Liver function is determined by estimating the activities of SGOT, SGPT, TBB, DBB and ALP that are original, present in higher concentration in the liver cell. During liver disease, these enzymes leak into the bloodstream in conformity with the extent of liver damage. ${ }^{17}$ The present study revealed a significant rise in the activities of SGOT, SGPT, TBB, DB and ALP due to $\mathrm{CCl}_{4}$ intoxication hepatic cell injury. The administration of different doses of ACE (100, 200 and 300 $\mathrm{mg} / \mathrm{kg}$ ) and silymarin traded group exhibited the lower label of SGOT, SGPT, TBB, DB and ALP compare to $\mathrm{CCl}_{4}$ treated group. The stabilization of SGOT, SGPT, BB, DB and ALP levels by ACE is a clear manifestation of the improvement of the functional status of the liver cells. The histopathological examination disclosed that the hepatic cells, central vein, and portal triad are almost normal in the ACE $(300 \mathrm{mg} / \mathrm{kg}$, p.o.) group in contrast to the group, which received $\mathrm{CCl}_{4}$.

Lipid peroxidation (LPO) is cell death due to the autocatalytic process. This process may cause peroxidative tissue damage in inflammation. MDA is one of the products in the lipid peroxidation process. ${ }^{18}$ The data obtained in our present study (Table 2) clearly shows an increase in the serum rat treated with $\mathrm{CCl}_{4}$ suggesting enhanced liver peroxidation leading to tissue damage and failure of antioxidant defence mechanism to prevent the formation of excessive free radicals. Treatment with ACE at $300 \mathrm{mg} / \mathrm{kg}$ significantly $93.99 \%$ $(\mathrm{P}<0.01)$ inhibited the formation of MDA levels in the $\mathrm{CCl}_{4}$ treated group and this is seen to be comparable with the standard drug silymarin.

In hepatic injury, superoxide radicals generate at the site of damage and modulate SOD and CAT, resulting in the loss of activity and accumulation of superoxide radicle, which damages the liver. ${ }^{19}$ The reduced levels of parameters of SOD

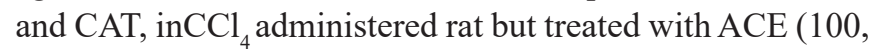
$200,300) \mathrm{mg} / \mathrm{kg}$ group of ACE showed the significant increase in the level of these enzymes, which observed the antioxidant property of ACE oxygen-free radicals. ${ }^{20}$

GSH is capable of preventing damage to important cellular components caused by ROS such as free radicals, peroxides, lipid peroxides, and heavy metals ${ }^{21}$ The intoxicants with $\mathrm{CCl} 4$ causes a reduction in the synthesis and functioning of
GSH. The increase in hepatic GSH level in rat treated with 100,200 and $300 \mathrm{mg} / \mathrm{kg}$ of ACE due to de novo GSH synthesis or GSH regeneration.

The phytochemical studies carried out on ACE reveal the presence of carbohydrates, alkaloids, phenols, flavonoids, saponins, tannins and triterpenoids. are the major chemical constituents. These antioxidant phytochemicals might contribute to the hepatoprotective and antioxidant activities of the whole plant of $A$. capillus.

\section{CONCLUSION}

This study showed that the $50 \%$ ethanolic extract of $A$. capillus. has hepatoprotective effects that were proven by biochemical and histopathological analysis. The ACE has shown dose-dependent activity among which at the dose level of $300 \mathrm{mg} / \mathrm{kg}$ p.o shows greater activity which comparable with a toxic and standard group.

\section{ACKNOWLEDGEMENT}

The authors are grateful to Mr. Rakesh Yadav and Mr. Vijay Kumar for technical assistance.

\section{Conflict of interest}

The authors declare that they have no conflicts of interest with the contents of this article.

\section{Funding source}

No financial support has been received.

\section{REFERENCES}

1. Patil A, Hoskeri HJ, Rajeev P, Kulkarni B, Kamble GR, Hiremath GB, et al. Hepatoprotective activity of methanolic shoot extract of Bambusa bamboos against carbon tetrachloride-induced acute liver toxicity in Wistar rats. J Appl Biol Biotechnol. 2018; 6(04):37-41.

2. Asadi M, Kafash N, Azimi N, Fasihi A, Alinia E, Rafieian M. Medicinal plants with hepatoprotective activity in Iranian folk medicine. Asian Pac J Trop Biomed. 2015; 5(2):146.

3. Gaikwad K, Dhande S, Joshi, Kadam V. Protective effect of Adiantum capillus against chemically induced oxidative stress by cisplatin. J Appl Pharmac Sci. 2013; 3(2):65.

4. Ansari R, Ekhlasi-Kazaj K. Adiantum capillus-veneris. L Phytochemical constituents, traditional uses and pharmacological properties, A review. J Adv Sci Res. 2012;3(4): 15.

5. Singh S, Khatoon S, Singh H, Behera S, Khare P, Rawat A. A report on pharmacognostical evaluation of four Adiantum species, Pteridophyta, for their authentication and quality control, Revista Brasileira de Farmacognosia. 2013;23(2):207.

6. Alqasoumi S. Carbon tetrachloride-induced hepatotoxicity: Protective effect of 'Rocket' Eruca sativa L. in rats. Am J Chin Med. 2010;38(1):75-88..

7. Husain A, Kaushik A, Awasthi H, Singh DP, Khan R, Mani D. Immunomodulatory and antioxidant activities of fresh 
juice extracts of Brahmi and Guduchi. Indian J Trad Knowl 2017;16(3):498-505.

8. Husain KA. Awasthi A, Singh DP, Khan R, Mani D. Antioxidant and hepatoprotective potential of Swaras and Hima extracts of Tinospora cordifolia and Boerhavia diffusa in Swiss albino mice. Pharmacog Mag. 2017;13(3):658.

9. Reddy GD, Rao CV, Shirwaikar A. Ethnomedical value of Cissampelos pareira extract in experimentally induced diarrhoea. Acta Pharmaceutica. 2004;54(1):27-35.

10. Rao GMM, Rao CV, Pushpangadan P, Shirwaikar A. Hepatoprotective effects of rubiadin, a major constituent of Rubia cordifolia Linn. J Ethnopharmacol. 2006; 103(3):484-490.

11. Jamall IS, Smith JC. Effects of cadmium on glutathione peroxidase, superoxide dismutase, and lipid peroxidation in the rat heart: a possible mechanism of cadmium cardiotoxicity. Toxicol Appl Pharmacol. 1985;80(1):33-42.

12. Tipple TE, Rogers LK. Methods for the determination of plasma or tissue glutathione levels. In Developmental Toxicology. Springer. 315-324.

13. El-Maraghy SA, Rizk SM, Shahin NN. Gastroprotective effect of crocin in ethanol-induced gastric injury in rats. Chem Biol Interac. 2015;229:26-35.

14. Gupta S, Haldar C, Ahmad R. Photoperiodic regulation of nuclear melatonin receptor ROR $\alpha$ in lymphoid organs of a tropical rodent Funambulus pennanti: Role in seasonal oxidative stress. J Photochem Photobiol B Biol. 2015;142:141-153.
15. Shokrzadeh M, Hosseinpour M, Habibi E, Antioxidant and protective effect of hydroalcoholic extract of Celtis australis L.on $\mathrm{CCl}_{4}$ induced hepatotoxicity. Pharmac Biomed Res. 2019;4(3):26-31.

16. Manjunatha B. Hepatoprotective activity of Pterocarpus santalinus Lf, an endangered medicinal plant. Indian J Pharmacol. 2006;38(1):25.

17. Gupta R, Hussain T, Panigrahi G, Das A, Singh GN, Sweety K, Faiyazuddin M, Rao CV. Hepatoprotective effect of Solanum xanthocarpum fruit extract against $\mathrm{CCl}_{4}$ induced acute liver toxicity in experimental animals. Asian Pac J Trop Med 2011;23:964-968.

18. Srinivasan R, Chandrashekar MJN, Nanjan MJ, Suresh B. Antioxdant activity of Caesalpinia digyana root. J Ethanopharmacol. 2007;1132:84-291.

19. Hussain Zeashan, G. Amresh, Singh S, Rao CV. Hepatoprotective and antioxidant activity of Amaranthus spinosus against $\mathrm{CCl}_{4}$ induced toxicity. J Ethnopharmacol. 2009;125:364-366.

20. Gupta RK, Swain SR, Sahoo J, Gupta A, Chaudhary nв. Hepatoprotective Potential of Trichosanthes dioica Roxb in Hepatotoxicity Induced by Simvastatin and its Consequences on Biochemical and Haematological Indice. Pharmacog J. 2018;10(4):720-724.

21. Zeashan H, Amresh G, Singh S, Rao CV. Hepatoprotective activity. Amranthus spinosus in experimental animals. Food Chem Toxicol. 2008;46(11);3417-3421.

Table 1: Effect of $\mathbf{5 0}_{\mathbf{0}} \%$ ethanolic extract of Adiantumm capillus (ACE) on biochemical parameters against $\mathbf{C C l}_{4}-$ induced liver toxicity in rat

\begin{tabular}{|c|c|c|c|c|c|c|}
\hline Group & $\begin{array}{l}\text { Treatment \& } \\
\text { Dose }(\mathrm{mg} / \mathrm{kg})\end{array}$ & SGOT (U/L) & SGPT (U/L) & $\begin{array}{l}\text { Total } \\
\text { bilirubin (mg/ } \\
\text { dL) }\end{array}$ & $\begin{array}{l}\text { Direct } \\
\text { bilirubin (mg/dL) }\end{array}$ & $\operatorname{ALP}(\mathrm{U} / \mathrm{L})$ \\
\hline I. & Control & $106.27 \pm 18.21$ & $48.50 \pm 8.21$ & $1.2 \pm 0.11$ & $0.17 \pm 0.01$ & $68.14 \pm 7.88$ \\
\hline II & $\mathrm{CCl}_{4}$ & $387.87 \pm 35.21^{* * *}$ & $233.27 \pm 23.86^{* * *}$ & $3.6 \pm 0.39^{* * *}$ & $1.30 \pm 0.03^{n+* t+}$ & $158.54 \pm 13.56^{n+t}$ \\
\hline III & $\begin{array}{l}\text { Silymarin (100 mg/ } \\
\mathrm{kg} \text { ) }\end{array}$ & $115.78 \pm 11.78^{* \star *}$ & $57 \cdot 35 \pm 6 n \cdot 62^{* * *}$ & $0.90 \pm 0.13^{* * *}$ & $0.386 \pm 0.025^{* * *}$ & $70.56 \pm 7.86^{4 * t}$ \\
\hline IV & ACE $(100 \mathrm{mg} / \mathrm{kg})$ & $270.55 \pm 22.24^{*}$ & $170 \pm 17 \cdot 32^{*}$ & $2.32 \pm 0.14^{*}$ & $1.01 \pm 0.094^{*}$ & $114.21 \pm 11.22^{*}$ \\
\hline V & ACE $(200 \mathrm{mg} / \mathrm{kg})$ & $186.55 \pm 18.80^{* * *}$ & $103.45 \pm 13.23^{* *}$ & $1.28 \pm 0.12^{* *}$ & $0.675 \pm 0.027^{* *}$ & $91.426 \pm 9.61^{* *}$ \\
\hline VI & ACE $(300 \mathrm{mg} / \mathrm{kg})$ & $112.81 . \pm 16.53^{* * *}$ & $58.24 \pm 6.80^{* * *}$ & $0.95 \pm 0.13^{* * *}$ & $0.423 \pm 0.027^{* * *}$ & $70.35 \pm 7.34^{* * *}$ \\
\hline
\end{tabular}

Value expressed as \pm S.E.M., $\mathrm{n}=6$, Significance level: ${ }^{*} \mathrm{P}<0.05$. ${ }^{* *} \mathrm{P}<0.01$ and ${ }^{* * *} \mathrm{P}<0.001, \mathrm{CCl}_{4}$ group compared to control while other group i.e treated group compared to $\mathrm{CCl}_{4}, 100 \mathrm{mg} / \mathrm{kg}, 200 \mathrm{mg} / \mathrm{kg}$ and $300 \mathrm{mg} / \mathrm{kg}$ represent the dose of $50 \%$ ethanolic extract of Adiantumm capillus

Table 2: Effect of $50 \%$ ethanolic extract of Adiantumm capillus (ACE) on liver LPO (MDA nmole/min//mg of protein), GSH parameters (nmole/min//mg of protein), SOD (unit/mg of protein) and CAT (unit/mg of protein against $\mathrm{CCl}_{4}$ induced liver toxicity in rat

$\begin{array}{llcccc}\text { Group } & \text { Treatment }(\mathrm{mg} / \mathrm{kg}) & \text { GSH }(\text { Mean } \pm \text { SEM }) & \text { LPO }(\text { Mean } \pm \text { SEM) } & \text { CAT }(\text { Mean } \pm \text { SEM }) & \text { SOD }(\text { Mean } \pm \text { SEM }) \\ \text { I } & \text { Control } & 0.96 \pm 0.08 & 0.40 \pm 0.09 & 58.58 \pm 6.62 & 26.5 \pm 2.92 \\ \text { II } & \text { CCl }{ }_{4} & 0.39 \pm 0.05^{* *} & 1.39 \pm 0.18^{* * *} & 35.23 \pm 2.40^{* * *} & 8.96 \pm 1.82^{* * *} \\ \text { III } & \text { Silymarin }(100 \mathrm{mg} / \mathrm{kg}) & 0.86 \pm 0.07^{* *} & 0.45 \pm 0.08^{* *} & 56.23 \pm 2.61^{* *} & 25.83 \pm 2.42^{* * *} \\ \text { IV } & \text { ACE }(100 \mathrm{mg} / \mathrm{kg}) & 0.53 \pm 0.06^{*} & 0.97 \pm 0.14^{*} & 44.62 \pm 2.72^{*} & 15.32 \pm 1.30^{*} \\ \text { V } & \text { ACE }(200 \mathrm{mg} / \mathrm{kg}) & 0.68 \pm 0.09^{*} & 0.66 \pm 0.17^{*} & 48.52 \pm 3.41^{*} & 20.52 \pm 2.83^{*} \\ \text { VI } & \text { ACE }(300 \mathrm{mg} / \mathrm{kg}) & 0.79 \pm 0.06^{* *} & 0.46 \pm 0.08^{* *} & 55.45 \pm 4.60^{* *} & 24.82 \pm 2.42^{* *}\end{array}$

Value expressed as \pm S.E.M., $\mathrm{n}=6$. Significance level: ${ }^{*} \mathrm{P}<0.05 .{ }^{* *} \mathrm{P}<0.01$ and ${ }^{* * t} \mathrm{P}<0.001$. $\mathrm{CCl}_{4}$ group compared to control while other group i.e treated group compared to $\mathrm{CCl}_{4}$. $100 \mathrm{mg} / \mathrm{kg}, 200 \mathrm{mg} / \mathrm{kg}$ and $300 \mathrm{mg} / \mathrm{kg}$ represent the dose of $50 \%$ ethanolic extract of Adiantumm capillus 


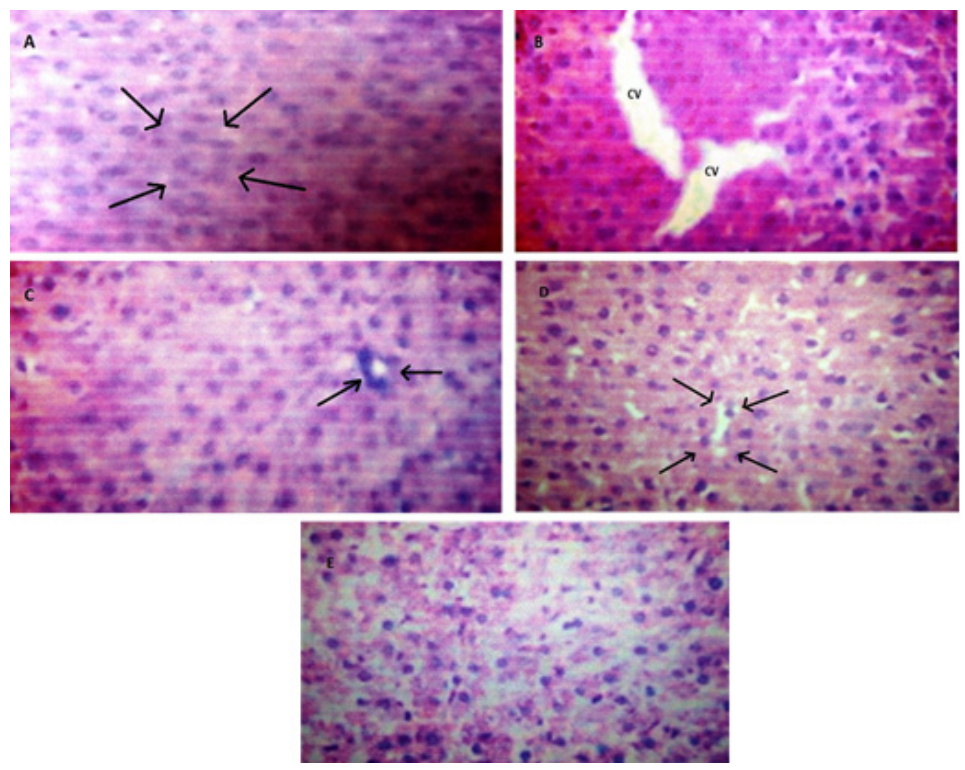

Figure 1: Histopathology of liver tissues. A. Normal liver section show prominent central vein, normal hepatocytes \& sinusoids; B. Toxic liver section shows massive fatty changes along with congestion in central vein; $\mathrm{C}$. Liver sections of rats treated $\mathrm{CCl}_{4}$ and ACE $100 \mathrm{mg} / \mathrm{kg}$ showing inflammatory collection around central vein \& focal necrosis with sinusoidal dilation; D. Liver section treated with $\mathrm{CCl}_{4}$ and $\mathrm{ACE} 200 \mathrm{mg} / \mathrm{kg}$ showing regeneration of hepatocytes around central vein toward near normal liver architecture; E. Liver section treated with $\mathrm{CCl}_{4}$ and ACE $300 \mathrm{mg} / \mathrm{kg}$ showing normal liver architecture. 